\title{
Total lymphocyte count in cancer patients with lymphopenia treated with intravenous vitamin C: Results of an observational study
}

\author{
Dolores Margarita Rodríguez ${ }^{1 *}$, Mery Elizabeth Guerrero', Bárbara Marisol Maldonado1', Claudia Vollbracht²,3 \\ and Sandra Aracely Herrera'
}

\begin{abstract}
Background: Lymphopenia commonly occurs in cancer patients and predicts poor prognosis. It is caused by radioand chemotherapy, with malnutrition and treatment-related oxidative stress playing key roles in its pathogenesis. Tumour-related morbidity is reported to be associated with reduced plasma ascorbate, which is a key physiological antioxidant and essential factor in immune function.

Method: A prospective observational study was conducted on 48 cancer patients with lymphopenia $(<1500 / \mu \mathrm{L})$ to investigate the total lymphocyte count (TLC) during four weeks of elective adjuvant treatment with intravenous (iv) vitamin C $7.5 \mathrm{~g}$ (Pascorbin ${ }^{\oplus} 7.5 \mathrm{~g}$ ) once a week. TLC values at baseline (just prior to start of treatment) and after 4 weeks treatment were compared using descriptive statistics.

Results: After 4 weeks iv vitamin C $7.5 \mathrm{~g}$, TLC increased by a mean of $211 / \mu \mathrm{L}(p=0.0018)$. Subgroup analyses showed that, in patients with severe lymphopenia $(n=25)(T L C<1000 / \mu L)$, the increase in TLC was greater with a mean rise of $368 / \mu \mathrm{L}(p=0.0004)$, than in patients $(n=23)$ with an initial TLC of $1000-1500$ (mean rise of $40 / \mu \mathrm{L})(p=0.6105)$. TLC increased by at least $240 / \mu \mathrm{L}$ in half of the patients with severe lymphopenia and by more than $610 / \mu \mathrm{L}$ in $25 \%$ of patients.

Conclusion: Our data indicate that iv high-dose vitamin C treatment increases TLC, which strongly implies improvement of immune function, especially in patients with severe lymphopenia. Appropriately-powered, randomized, placebo-controlled trials of iv high-dose vitamin C are now needed to define more precisely its role in the treatment of cancer-related lymphopenia and how this impacts on the patients' clinical prognosis.
\end{abstract}

Keywords: Ascorbate, Lymphopenia, TLC, Neoplasms

\section{Background}

Severe treatment-related hematological toxicities, such as lymphopenia, occur commonly in many cancers [1]. Drastically reduced TLC increases the risk of various forms of infections [2]. Recent studies reveal an association of post-treatment lymphopenia and decreased survival in patients with solid tumours who underwent chemo- or radiotherapy [1, 3-5]. Adjuvant treatment options are needed to restore this reversible prognostic factor.

Ascorbate, the absorbed form of dietary vitamin C, is an essential factor for immune cells and enhances the

\footnotetext{
* Correspondence: dra.rodriguezv@yahoo.com

${ }^{1}$ Clinical Nutrition Department, SOLCA Cancer Hospital, Guayaquil, Ecuador Full list of author information is available at the end of the article
}

immune system in many ways [6, 7]. It enhances leukocyte function and innate immune responses via modulation of chemokinesis and chemotaxis [8]. Leukocytes actively accumulate ascorbate to achieve intracellular concentrations that exceed plasma concentrations by up to 80-fold [9].

Cancer patients are often reported to be vitamin C deficient [10-18]. Particularly serious are the deficiencies in patients with advanced cancer $[15,19,20]$, where decreased plasma ascorbate levels are associated with shorter survival and impaired quality of life [21].

Intravenous (iv) instead of oral administration of ascorbate is required in order to achieve the high plasma concentrations [22] that have been shown to have 
potential therapeutic effects [23, 24]. Ten years ago, high dose vitamin $C$ (as sodium ascorbate) was found to have selective tumour cytotoxic effects [25] and its chemotherapeutic potential is still undergoing investigation [26]. Several phase I/Ila studies examined the chemotherapeutic effects of iv high-dose vitamin $\mathrm{C}$ as an adjuvant to standard treatment in patients with advanced tumours [27-29]. Another potential benefit of iv vitamin $\mathrm{C}$ treatment is the favourable effect on the quality of life of cancer patients [30-32]. Although iv high dose vitamin $\mathrm{C}$ is a popular complementary treatment in the management of cancer conditions [23, 24, 33], there is, as far as we are aware, no published data on its effects on lymphopenia.

The aim of this observational study was the evaluation of the effects of iv high-dose vitamin $\mathrm{C}$ on lymphopenia in cancer patients.

\section{Methods}

The objective of this prospective observational study was to document the use of Pascorbin $7.5 \mathrm{~g}$ (licensed, proprietary medicinal product containing $7.5 \mathrm{~g}$ ascorbate for iv infusion; license owner: Pascoe Pharmazeutische Präparate $\mathrm{GmbH}$, Germany) in patients with advanced cancer and lymphopenia, and to monitor its effect on their TLC. Data were collected from those cancer patients attending the ambulatory service of the Clinical Nutrition Department at SOLCA Cancer Hospital, Guayaquil, Ecuador, from February 2012 to October 2014, and who received elective iv ascorbate treatment as an adjuvant to tumour therapy. It was the physicians' decision to use the infusion in accordance to the indication as an adjuvant to tumour therapy with the aims of to speed up postoperative recovery, to reduce the side effects of conventional oncological therapy (such as chemotherapy, radiotherapy), to reduce periods of hospitalization, to prolong the tumour- and recurrencefree intervals and to improve quality of life. As lymphopenia is a chemotherapy or radiation related hematological side effect, the treatment with iv vitamin $\mathrm{C}$ is covered by the approved indication.

The study included 48 cancer patients (aged $\geq 18$ years) with lymphopenia, defined as a TLC below $1500 / \mu \mathrm{L}$ blood [2,34]. Diagnosis of cancer was previously confirmed and documented by the attending physician. Malignant neoplasm of cervix uteri $(n=11)$ was the most common $(22.9 \%)$ cancer documented in the study group, followed by breast cancer (14.6\%), with between 2.1 and $8.3 \%$ for other cancer types. The study was a non-interventional study aimed to document the routine clinical use of iv vitamin C. Patients agreed, in a signed statement, to study participation and to release of their data. The criteria for patient selection are listed in Table 1.
Table 1 Patient data eligibility criteria

Inclusion criteria
Aged $\geq 18$
Vitamin C deficiency (due to the underlying cancer disease or
treatment)
Previously confirmed cancer diagnosis with previous or current
radiation- and/or chemotherapy
Total lymphocyte count $<1500 / \mu \mathrm{L}$
Treatment with iv vitamin C $7.5 \mathrm{~g}$ once a week, for a total of 4 doses
Patient's statement of agreement to use and publish their data for
the observational study
Exclusion criteria (anamnestic)
Patients who received colony-stimulating factor
Patients not completing all four doses of iv vitamin C
Oxalate-urolithiasis, nephrolithiasis
Renal insufficiency
Iron-storage disease (thalassemia, hämochromatosis, sideroblastic
anaemia)
Erythrocytic glucose-6-phosphate-dehydrogenase-deficiency
Pregnancy and lactation

Once a week, patients received iv vitamin C $7.5 \mathrm{~g}$ (Pascorbin $^{\circ}$ ), diluted in a suitable carrier solution, such as $100 \mathrm{~mL} \mathrm{NaCL} 0.9 \%$. Data were collected before the start of vitamin $\mathrm{C}$ treatment (visit 1, baseline) and after 4 weeks of treatment.

\section{Total lymphocyte count (TLC)}

The main study parameter was the change in TLC from baseline to 4 weeks. A quantitative multi-parameter automated hematology analyser (xn 3000 series, sysmex) was used for all patients to measure TLC in peripheral blood samples obtained by venipuncture. The onesample t-test (two-sided, with $\alpha=0.05$ ) was used to test for significance of the mean change. Additional, separate analyses were carried out on data from patients with TLC of $<1000 / \mu \mathrm{L}$ (severe lymphopenia) and patients with TLCs of 1000-1500 lymphocytes/ $\mu \mathrm{L}$ before start of treatment. The statistical analyses were performed by an independent statistician.

\section{Nutritional status}

Due to the lack of an universally accepted definition of malnutrition, our classification of the nutrition status (Table 2) is based on a combination of patient's body mass index (BMI) [35] together with a scored PatientGenerated Subjective Global Assessment (PG-SGA) [36], and the Nutritional Risk Screening (NRS) [37]. The BMI allows us to classify overweight or obese patients. Risk of malnutrion $(\mathrm{BMI}<20.5)$ is defined by NRS and the combination of BMI with the PG-SGA allows us to 
Table 2 Baseline demographic and clinical characteristics of patients

\begin{tabular}{ll}
\hline Characteristics & BaselineNisit $1(n=48)$ \\
\hline Age, years mean \pm SD; range & \\
Total & $56.4 \pm 15.7 ; 17-84$ \\
Male & $53.8 \pm 15.4 ; 17-73$ \\
Female & $57.1 \pm 15.9 ; 24-84$ \\
Sex, $n(\%)$ & \\
Male & $10(20.8 \%)$ \\
Female & $38(79.2 \%)$ \\
Nutrition status, n (\%) & \\
Normal & $0(0.0 \%)$ \\
Risk of malnutrition & $10(20.8 \%)$ \\
Mild malnutrition & $3(6.3 \%)$ \\
Moderate malnutrition & $17(35.4 \%)$ \\
Severe malnutrition & $12(25.0 \%)$ \\
Overweight & $2(4.2 \%)$ \\
Obesity Grade 1 & $4(8.3 \%)$ \\
\hline
\end{tabular}

differentiate further to mild, moderate or severe malnutrition.

The safety of the vitamin $C$ treatment was assessed by the attending physician in terms of adverse events and possible relatedness of such events to vitamin $\mathrm{C}$ treatment.

\section{Results}

A total of 48 patients (mean \pm standard deviation of age, $56.4 \pm 15.7$ years; $79.2 \%$ female) with previously confirmed neoplasms were included in the study and all were included in our analysis. Of note, more than half of the patients $(60.4 \%)$ displayed moderate or severe malnutrition (Table 2). The mean TLC increased significantly $(p=0.0018)$ from $902.0 / \mu \mathrm{L} \quad( \pm 414 / \mu \mathrm{L})$ at baseline to $1113 / \mu \mathrm{l}( \pm 466 / \mu \mathrm{L})$ after 4 weeks treatment. This was a mean increase in TLC of $211 / \mu \mathrm{L}$ $( \pm 442 / \mu \mathrm{L})$. In patients with $<1000$ lymphocytes $/ \mu \mathrm{L}$ (severe lymphopenia), the mean increase at 4 weeks was $368 / \mu \mathrm{L}( \pm 449 / \mu \mathrm{L})(p=0.0004)$ compared to an increase of $40 / \mu \mathrm{L}( \pm 372 / \mu \mathrm{L})(p=0.6105)$ in patients with an initial TLC of 1000-1500 lymphocytes/ $\mu \mathrm{L} \quad(n=23)$ (Table 3).

Patients in our study group who were at risk of malnutrition or mild malnutrition had initial TLC values of $>1000$ / $\mu \mathrm{L}$ (mean TLC $1046.9 / \mu \mathrm{L}$ and $1270.0 / \mu \mathrm{L}$, respectively), whereas the initial mean TLC in patients with moderate or severe malnutrition was $<1000 / \mu \mathrm{L}(846.5 / \mu \mathrm{L}$ and $774.2 / \mu \mathrm{L}$,

Table 3 Total lymphocytes count (TLC) at start and at end of treatment

\begin{tabular}{|c|c|c|c|c|}
\hline & $\begin{array}{l}\text { TLC at start of } \\
\text { treatment [cells } / \mu \mathrm{L}]\end{array}$ & $\begin{array}{l}\text { TLC at end of } \\
\text { treatment [cells/ } \mu \mathrm{L}]\end{array}$ & $\begin{array}{l}\text { Difference } \\
\text { (end - start)[cells } / \mu \mathrm{L}]\end{array}$ & probability estimate \\
\hline \multicolumn{5}{|l|}{ All patients $n=48$} \\
\hline $\begin{array}{l}\text { Mean value } \pm S D \text {; } \\
\text { range }\end{array}$ & $\begin{array}{l}902 \pm 414 \\
130-1499\end{array}$ & $\begin{array}{l}1113 \pm 466 \\
220-1135\end{array}$ & $\begin{array}{l}211 \pm 442 \\
-1110-1900\end{array}$ & \multirow[t]{4}{*}{$p=0.0018$} \\
\hline 25\% Percentile & 532.5 & 742.5 & 25.0 & \\
\hline 50\% Percentile (Median) & 920.0 & 1135.0 & 115.0 & \\
\hline 75\% Percentile & 1315.0 & 1440.0 & 395.0 & \\
\hline \multicolumn{5}{|c|}{ Patients with severe lymphopenia (lymphocytes $<1000 / \mu \mathrm{L}$ ) $n=25$} \\
\hline $\begin{array}{l}\text { Mean value } \pm S D \text {; } \\
\text { range }\end{array}$ & $\begin{array}{l}551 \pm 212 \\
130-960\end{array}$ & $\begin{array}{l}919 \pm 447 \\
380-2420\end{array}$ & $\begin{array}{l}368 \pm 449 \\
-110-1900\end{array}$ & \multirow[t]{4}{*}{$p=0.0004$} \\
\hline 25\% Percentile & 390.0 & 585.0 & 30.0 & \\
\hline 50\% Percentile (Median) & 540.0 & 820.0 & 240.0 & \\
\hline 75\% Percentile & 705.0 & 1180.0 & 610.0 & \\
\hline \multicolumn{5}{|c|}{ Patients without moderate lymphopenia (lymphocytes $1000-1500 / \mu \mathrm{L}$ ) $n=23$} \\
\hline $\begin{array}{l}\text { Mean value } \pm S D \\
\text { range }\end{array}$ & $1283 \pm 161 ; 1000-1499$ & $\begin{array}{l}1323 \pm 396 \\
220-1870\end{array}$ & $\begin{array}{l}40 \pm 372 \\
-1110-660\end{array}$ & \multirow[t]{4}{*}{$p=0.6105$} \\
\hline 25\% Percentile & 1120.0 & 1150.0 & 20.0 & \\
\hline 50\% Percentile (Median) & 1320.0 & 1400.0 & 100.0 & \\
\hline 75\% Percentile & 1180.0 & 1620.0 & 180.0 & \\
\hline
\end{tabular}

SD standard deviation

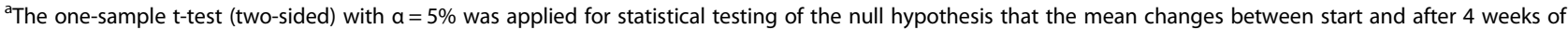
treatment are equal to 0 
respectively) (Table 4, Fig. 1). TLC at begin and at end of treatment for each patient are available in Table 5 .

In the study group, no adverse effects related to iv vitamin $\mathrm{C}$ were observed.

\section{Discussion}

Our non-interventianal study provides evidence that iv high-dose vitamin $\mathrm{C}$ reverses lymphopenia in cancer patients. We included radiotherapy- or chemotherapytreated cancer patients with a TLC of $<1500 / \mu \mathrm{L}$, which was our definition of lymphopenia [2]. The data indicated a significant increase in the mean TLC value for the whole group while a subgroup analysis revealed a more significant effect in patients with a TLC of $<1000 / \mu \mathrm{L}$.

Several published reports suggest that lymphopenia is a reversible, predictive factor for earlier tumour progression/relapse and reduced survival, as indicated in several retrospective studies $[3-5,38,39]$. Poor prognosis of cancer patients is indicated by a TLC value of $<1000 / \mu \mathrm{L}$ [39] [38] and is more evident with TLC values of $<500$ / $\mu \mathrm{L}[3,5]$. More than $35 \%$ of our patients with an initial mean TLC of $551 / \mu \mathrm{L}( \pm 212)$ had a TLC of $>1000 / \mu \mathrm{L}$ after 4 weeks of iv vitamin $\mathrm{C}$ treatment. Given the increased risk of progression and mortality in severe lymphopenia, a TLC increase to $>1000 / \mu \mathrm{L}$ is a clinically relevant and significant improvement.

The reasons for lymphopenia can be diverse [40]. In our study group, it is presumably lymphocyte depletion primarily due to radiotherapy and chemotherapy [40]. Severe stress, malnutrition and protein-energy undernutrition can also cause lymphopenia [2]. Moderate-tosevere malnutrition was evident in more than half of the patients $(60.4 \%)$ in our study group and was probably a

Table 4 Mean total lymphocytes counts (TLC) for patients of differing nutritional status

\begin{tabular}{|c|c|c|c|}
\hline Nutrition status & $\begin{array}{l}\text { Lymphocytes } \\
\text { before therapy } \\
\text { mean }[\text { cells/ } \mu \mathrm{L}]\end{array}$ & $\begin{array}{l}\text { Lymphocytes } \\
\text { after therapy } \\
\text { mean }[\text { cells/ } \mu \mathrm{L}]\end{array}$ & $\begin{array}{l}\text { Difference in } \\
\text { Lymphocytes } \\
\text { mean }[\text { cells } / \mu \mathrm{L}]\end{array}$ \\
\hline Normal $=0$ & - & - & - \\
\hline $\begin{array}{l}\text { Risk of malnutrition } \\
n=10\end{array}$ & 1046.9 & 1334.0 & 287.1 \\
\hline $\begin{array}{l}\text { Mild malnutrition } \\
n=3\end{array}$ & 1270.0 & 1096.7 & $-173.3^{a}$ \\
\hline $\begin{array}{l}\text { Moderate } \\
\text { malnutrition } n=17\end{array}$ & 846.5 & 1013.5 & 167.1 \\
\hline $\begin{array}{l}\text { Severe malnutrition } \\
n=12\end{array}$ & 774.2 & 1013.3 & 239.2 \\
\hline Overweight $n=2$ & 615.0 & 1620.0 & 1005.0 \\
\hline $\begin{array}{l}\text { Obesity Grade } 1 \\
n=4\end{array}$ & 1025.0 & 1035.0 & 10.0 \\
\hline Valid data & 48 & 48 & 48 \\
\hline Missing data & 0 & 0.0 & 0 \\
\hline
\end{tabular}

${ }^{a}$ negative values means a decrease of lymphocytes

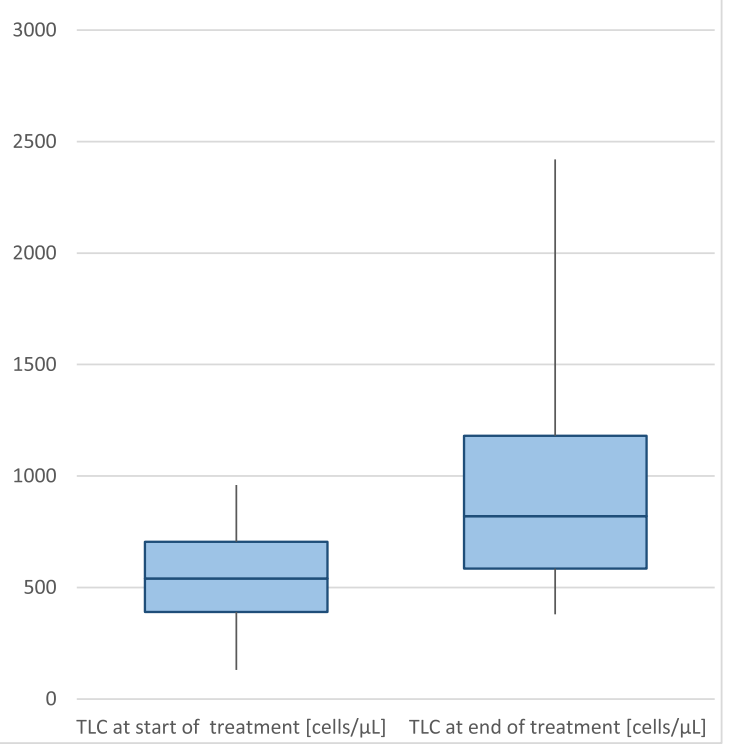

Fig. 1 Total lymphocytes count (TLC) before and after 4-week iv high-dose vitamin C treatment. The Box Plot displays the data of the study group with initial TLC $<1000 \mu \mathrm{L}$. Vertical bar indicates standard deviation, box indicates $25 \%$, median, $75 \%$ percentile

contributory factor to the lymphopenia. The small size of our study group may explain the absence of statistical significance of any association between nutritional status and lymphocyte counts at the start of treatment. However, we did observe a correlation between risk of malnutrition and lymphopenia in our study group (Table 4 and Fig. 1).

The beneficial effect of iv vitamin C on TLC values in cancer patients is most likely due to its antioxidant actions counteracting treatment-induced oxidative stress. This was also suggested to explain the positive clinical effects of iv high-dose vitamin $\mathrm{C}$ observed in other cancer patients $[29,30,41]$. Oxidative stress is considered to be an underlying cause of lymphopenia of different etiologies [42], such as that caused by intensive exercise [43], endstage renal disease patients [44] and AZT ( $3^{\prime}$-azido-2' $3^{\prime}$ dideoxythimidine) (an AIDS treatment). This notion is supported by animal data showing that high-dose antioxidants abrogate experimentally-induced lymphopenia [45].

A contributory factor for the favourable effect of vitamin $C$ could be its function as a cofactor in the synthesis carnitine [46], which supports immune cell function, $s$ predominantly through carnitine-dependent energy metabolism of fatty acids. Carnitine deficiency has been demonstrated in patients with impaired immune responses [47]. The ability of vitamin $C$ to increase endogen carnitine synthesis and thereby improving energy metabolism is supported by animal data [46].

The supportive effect of iv vitamin $C$ on the immune system that we have observed is supported by other 
Table 5 TLC at begin and end of treatment for each patient

\begin{tabular}{|c|c|c|c|}
\hline $\begin{array}{l}\text { Lymphocytes } \\
\text { at begin }\end{array}$ & $\begin{array}{l}\text { Lymphocytes } \\
\text { at end }\end{array}$ & $\begin{array}{l}\text { Lymphocytes - Difference } \\
\text { (post - pre) }\end{array}$ & $\begin{array}{l}\text { Lymphocytes - } \\
\text { status }\end{array}$ \\
\hline 1430 & 1450 & 20 & $\geq 1000$ \\
\hline 1330 & 220 & -1110 & $\geq 1000$ \\
\hline 880 & 1460 & 580 & $<1000$ \\
\hline 520 & 2420 & 1900 & $<1000$ \\
\hline 1499 & 1620 & 121 & $\geq 1000$ \\
\hline 1300 & 1400 & 100 & $\geq 1000$ \\
\hline 680 & 920 & 240 & $<1000$ \\
\hline 700 & 740 & 40 & $<1000$ \\
\hline 1250 & 1320 & 70 & $\geq 1000$ \\
\hline 1440 & 1620 & 180 & $\geq 1000$ \\
\hline 1350 & 1630 & 280 & $\geq 1000$ \\
\hline 1130 & 460 & -670 & $\geq 1000$ \\
\hline 420 & 880 & 460 & $<1000$ \\
\hline 810 & 770 & -40 & $<1000$ \\
\hline 1410 & 1330 & -80 & $\geq 1000$ \\
\hline 550 & 1280 & 730 & $<1000$ \\
\hline 130 & 510 & 380 & $<1000$ \\
\hline 1060 & 910 & -150 & $\geq 1000$ \\
\hline 290 & 1030 & 740 & $<1000$ \\
\hline 1490 & 1580 & 90 & $\geq 1000$ \\
\hline 440 & 1080 & 640 & $<1000$ \\
\hline 660 & 680 & 20 & $<1000$ \\
\hline 960 & 1060 & 100 & $<1000$ \\
\hline 1120 & 1230 & 110 & $\geq 1000$ \\
\hline 580 & 750 & 170 & $<1000$ \\
\hline 1420 & 1710 & 290 & $\geq 1000$ \\
\hline 760 & 1310 & 550 & $<1000$ \\
\hline 370 & 380 & 10 & $<1000$ \\
\hline 1080 & 1690 & 610 & $\geq 1000$ \\
\hline 280 & 1410 & 1130 & $<1000$ \\
\hline 830 & 720 & -110 & $<1000$ \\
\hline 630 & 1290 & 660 & $<1000$ \\
\hline 1250 & 1380 & 130 & $\geq 1000$ \\
\hline 1030 & 1180 & 150 & $\geq 1000$ \\
\hline 1000 & 1120 & 120 & $\geq 1000$ \\
\hline 1420 & 1670 & 250 & $\geq 1000$ \\
\hline 530 & 570 & 40 & $<1000$ \\
\hline 1100 & 1150 & 50 & $\geq 1000$ \\
\hline 380 & 400 & 20 & $<1000$ \\
\hline 490 & 510 & 20 & $<1000$ \\
\hline 710 & 820 & 110 & $<1000$ \\
\hline 400 & 440 & 40 & $<1000$ \\
\hline 540 & 940 & 400 & $<1000$ \\
\hline
\end{tabular}

Table $\mathbf{5} \mathrm{TLC}$ at begin and end of treatment for each patient (Continued)

\begin{tabular}{llll}
\hline 1210 & 1870 & 660 & $\geq 1000$ \\
1320 & 1400 & 80 & $\geq 1000$ \\
1450 & 1500 & 50 & $\geq 1000$ \\
1420 & 990 & -430 & $\geq 1000$ \\
240 & 600 & 360 & $<1000$ \\
\hline
\end{tabular}

published findings (such as, stimulation of natural killer cell activity by high dose vitamin C [48]). Furthermore, our data may relate to the increased quality of life and prolonged survival time observed in in phase I/IIa clinical trials of cancer patients treated with iv vitamin $C[28,29]$.

Intravenous high-dose vitamin $\mathrm{C}$ treatment was well tolerated by our patients, which is consistent with data from other clinical studies and comprehensive clinical surveys indicating the good tolerability of iv high-dose vitamin $\mathrm{C}$ up to $0.5 \mathrm{~g} / \mathrm{kg}$ body weight (in phase-I-trials even up to $1.5 \mathrm{~g} / \mathrm{kg}$ ) when contraindications are complied with [23, 27, 33, 49, 50].

As we are aware, our study provides the first evidence that iv high-dose vitamin $C$ treatment improves the immune status of cancer patients treated in daily clinical practice, and that the treatment is well-tolerated by this patient group. However, the clinical interpretation of our data is limited by the absence of a control group and the small size of our study group.

\section{Conclusion}

This study provides "real-life" observational evidence of the use of iv high-dose vitamin $C$ in daily practice in the treatment of cancer patients with lymphopenia. Patients with severe lymphopenia seem to particularly benefit from iv vitamin $C$ with a clinically significant increase in TLC. Appropriately-powered, randomized, placebocontrolled trials of iv high-dose vitamin $\mathrm{C}$ are now needed to define more precisely its role in the treatment of cancer-related lymphopenia and how this impacts on the patients' clinical prognosis.

\footnotetext{
Abbreviations

iv: Intravenous; NIS: Non-interventional stud; TLC: Total lymphocyte count

Acknowledgements

The authors thank Professor Gerard Patrick McGregor PhD (OmniScience SA) for his scientific editing of the manuscript.

Funding

Laboratory determination of TLC was part of routine labor. Charges for the independent statistician and the language editing service as well as the article-processing charge for the open-access journal were sponsored by Pascoe Natural Medicine, Germany.

Availability of data and materials

TLC at begin and at end of treatment for each patient are available in Table 5 without patient number, because of data protection purposes.
} 


\section{Authors' contributions}

DRV conceived and initiated the study and carried out data evaluation. GTM, $M M V$, and SHM participated in study design, coordination and data evaluation. $\mathrm{CV}$ drafted the manuscript and participated in data evaluation. All authors read and approved the final manuscript. The statistical analyses were performed by an independent statistician (Gesellschaft für Therapieforschung mbH, www.gkm-therapieforschung.de, Munich, Germany).

\section{Competing interests}

DRV, GTM, MMV, and SHM declare that they have no competing interests and received no funding for this observational study. CV is employed by Pascoe Pharmazeutische Präparate GmbH (Giessen, Germany).

\section{Consent for publication}

Not applicable.

\section{Ethics approval and consent to participate}

The objective of this prospective observational study was to document the use of an authorized medicinal product. Data were collected from those cancer patients who received elective iv ascorbate treatment as an adjuvant to tumour therapy (non-interventional study; NIS). Because this type of study documents the effects of medical routine without given intervention an ethics committee vote is not necessary. According to the ICMJE definition of a clinical trial purely observational studies (those in which the assignment of the medical intervention is not at the discretion of the investigator) will not require registration.

Patients agreed with the study participation and data processing, which was assured by a signed statement.

\section{Author details}

'Clinical Nutrition Department, SOLCA Cancer Hospital, Guayaquil, Ecuador. ${ }^{2}$ Hochschule Fresenius, University of Applied Sciences, 65510 Idstein, Germany. ${ }^{3}$ Pascoe Pharmazeutische Präparate GmbH, Giessen, Germany.

Received: 5 July 2016 Accepted: 16 February 2017

Published online: 10 March 2017

\section{References}

1. Grossman SA, Ellsworth S, Campian J, Wild AT, Herman JM, Laheru D, Brock M, Balmanoukian A, Ye X. Survival in patients with severe lymphopenia following treatment with radiation and chemotherapy for newly diagnosed solid tumors. J Natl Compr Cancer Netw. 2015;13(10):1225-31.

2. Merck Manual: Lymphocytopenia - Hematology and Oncology - Merck Manuals Professional Edition. [http://www.merckmanuals.com/professional/ hematology-and-oncology/leukopenias/lymphocytopenia].

3. Wild AT, Ye X, Ellsworth SG, Smith JA, Narang AK, Garg T, Campian J, Laheru $D A$, Zheng $L$, Wolfgang $C L$, et al. The association between chemoradiationrelated lymphopenia and clinical outcomes in patients with locally advanced pancreatic adenocarcinoma. Am J Clin Oncol. 2015;38(3):259-65.

4. Wu ES, Oduyebo T, Cobb LP, Cholakian D, Kong X, Fader AN, Levinson KL, Tanner EJ, 3rd, Stone RL, Piotrowski A, et al. Lymphopenia and its association with survival in patients with locally advanced cervical cancer. Gynecol Oncol. 2016;140(1):76-82

5. Campian JL, Sarai G, Ye X, Marur S, Grossman SA. Association between severe treatment-related lymphopenia and progression-free survival in patients with newly diagnosed squamous cell head and neck cancer. Head Neck. 2014; 36(12):1747-53.

6. Panush RS, Delafuente JC. Vitamins and immunocompetence. World Rev Nutr Diet. 1985:45:97-132.

7. Strohle A, Hahn A. Vitamin C and immune function. Med Monatsschr Pharm. 2009:32(2):49-54. quiz 55-46.

8. Schwager J, Bompard A, Weber P, Raederstorff D. Ascorbic acid modulates cell migration in differentiated HL-60 cells and peripheral blood leukocytes. Mol Nutr Food Res. 2015:59(8):1513-23.

9. Moser U. Uptake of ascorbic acid by leukocytes. Ann N Y Acad Sci. 1987:498:200-15.

10. Abou-Seif MA, Rabia A, Nasr M. Antioxidant status, erythrocyte membrane lipid peroxidation and osmotic fragility in malignant lymphoma patients. Clin Chem Lab Med. 2000;38(8):737-42.

11. Neyestani TR, Fereydouni Z, Hejazi S, Salehi-Nasab F, Nateghifard F, Maddah M, Karandish M. Vitamin C status in Iranian children with acute lymphoblastic leukemia: evidence for increased utilization. J Pediatr Gastroenterol Nutr. 2007; 45(1):141-4.

12. Chevion S, Or R, Berry EM. The antioxidant status of patients subjected to total body irradiation. Biochem Mol Biol Int. 1999:47(6):1019-27.

13. Tsai SM, Lin SK, Lee KT, Hsiao JK, Huang JC, Wu SH, Ma H, Wu SH, Tsai LY. Evaluation of redox statuses in patients with hepatitis B virus-associated hepatocellular carcinoma. Ann Clin Biochem. 2009;46(Pt 5):394-400.

14. Sakhi AK, Russnes KM, Thoresen M, Bastani NE, Karlsen A, Smeland S, Blomhoff R. Pre-radiotherapy plasma carotenoids and markers of oxidative stress are associated with survival in head and neck squamous cell carcinoma patients: a prospective study. BMC Cancer. 2009;9:458.

15. Mahdavi R, Faramarzi E, Seyedrezazadeh E, Mohammad-Zadeh M, Pourmoghaddam M. Evaluation of oxidative stress, antioxidant status and serum vitamin C levels in cancer patients. Biol Trace Elem Res. 2009;130(1):1-6.

16. Surapaneni KM, Ramana V. Erythrocyte ascorbic acid and plasma vitamin E status in patients with carcinoma of prostate. Indian J Physiol Pharmacol. 2007:51(2):199-202.

17. Esme H, Cemek M, Sezer M, Saglam H, Demir A, Melek H, Unlu M. High levels of oxidative stress in patients with advanced lung cancer. Respirology. 2008;13(1):112-6.

18. Al-Gayyar MM, Eissa LA, Rabie AM, El-Gayar AM. Measurements of oxidative stress status and antioxidant activity in chronic leukaemia patients. J Pharm Pharmacol. 2007:59(3):409-17.

19. Shah FD, Patel JB, Shukla SN, Shah PM, Patel PS. Evaluation of plasma non-enzymatic antioxidants in breast cancer etiology. Asian Pac J Cancer Prev. 2009;10(1):91-6.

20. Marcus SL, Petrylak DP, Dutcher JP, Paietta E, Ciobanu N, Strauman J, Wiernik PH, Hutner SH, Frank O, Baker H. Hypovitaminosis C in patients treated with high-dose interleukin 2 and lymphokine-activated killer cells. Am J Clin Nutr. 1991:54(6 Suppl):1292S-7.

21. Mayland CR, Bennett Ml, Allan K. Vitamin C deficiency in cancer patients. Palliat Med. 2005:19(1):17-20.

22. Levine M, Rumsey SC, Daruwala R, Park JB, Wang Y. Criteria and recommendations for vitamin C intake. JAMA. 1999:281(15):1415-23.

23. Padayatty SJ, Sun AY, Chen Q, Espey MG, Drisko J, Levine M. Vitamin C: intravenous use by complementary and alternative medicine practitioners and adverse effects. PLoS One. 2010;5(7):e11414.

24. Levine M, Padayatty SJ, Espey MG. Vitamin C: concentration- function approach yields pharmacology and therapeutic discoveries. Adv Nutr. 2011;2:78-88.

25. Chen Q, Espey MG, Krishna MC, Mitchell JB, Corpe CP, Buettner GR, Shacter E, Levine M. Pharmacologic ascorbic acid concentrations selectively kill cancer cells: action as a pro-drug to deliver hydrogen peroxide to tissues. Proc Natl Acad Sci. USA 2005;102(38):13604-609.

26. Yun J, Mullarky E, Lu C, Bosch KN, Kavalier A, Rivera K, Roper J, Chio II, Giannopoulou EG, Rago C, et al. Vitamin C selectively kills KRAS and BRAF mutant colorectal cancer cells by targeting GAPDH. Science. 2015; 350(6266):1391-6.

27. Monti DA, Mitchell E, Bazzan AJ, Littman S, Zabrecky G, Yeo CJ, Pillai MV Newberg AB, Deshmukh S, Levine M. Phase I evaluation of intravenous ascorbic acid in combination with gemcitabine and erlotinib in patients with metastatic pancreatic cancer. PLoS One. 2012;7(1):e29794.

28. Welsh JL, Wagner BA, van't Erve TJ, Zehr PS, Berg DJ, Halfdanarson TR, Yee NS, Bodeker KL, Du J, Roberts 2nd LJ, et al. Pharmacological ascorbate with gemcitabine for the control of metastatic and node-positive pancreatic cancer (PACMAN): results from a phase I clinical trial. Cancer Chemother Pharmacol. 2013;71(3):765-75.

29. Ma Y, Chapman J, Levine M, Polireddy K, Drisko J, Chen Q. High-dose parenteral ascorbate enhanced chemosensitivity of ovarian cancer and reduced toxicity of chemotherapy. Sci Transl Med. 2014:6(222):222ra218.

30. Vollbracht C, Schneider B, Leendert V, Weiss G, Auerbach L, Beuth J. Intravenous vitamin $C$ administration improves quality of life in breast cancer patients during chemo-/radiotherapy and aftercare: results of a retrospective, multicentre, epidemiological cohort study in Germany. In Vivo. 2011:25(6):983-90

31. Yeom CH, Jung GC, Song KJ. Changes of terminal cancer Patients' healthrelated quality of life after high dose vitamin $\mathrm{C}$ administration. J Korean Med Sci. 2007;22(1):7-11.

32. Takahashi $\mathrm{H}$, Mizuno $\mathrm{H}$, Yanagisawa A. High-dose intravenous vitamin $\mathrm{C}$ improves quality of life in cancer patients. Personal Med Univ. 2012;1:49-53.

33. Mikirova N, Casciari J, Riordan N, Hunninghake R. Clinical experience with intravenous administration of ascorbic acid: achievable levels in blood for 
different states of inflammation and disease in cancer patients. J Transl Med. 2013;11(1):191.

34. Berezne A, Bono W, Guillevin L, Mouthon L. Diagnosis of lymphocytopenia. Presse Med. 2006;35(5 Pt 2):895-902.

35. BMl classification [http://apps.who.int/bmi/index.jsp?introPage=intro_3.html].

36. Bauer J, Capra S, Ferguson M. Use of the scored Patient-Generated Subjective Global Assessment (PG-SGA) as a nutrition assessment tool in patients with cancer. Eur J Clin Nutr. 2002:56(8):779-85.

37. Kondrup J, Rasmussen HH, Hamberg O, Stanga Z. Nutritional risk screening (NRS 2002): a new method based on an analysis of controlled clinical trials. Clin Nutr (Edinburgh, Scotland). 2002;22(3):321-36.

38. Wei X, Wei $Y$, Huang F, Jing $H$, Xie M, Hao X, Feng R. Lymphopenia predicts preclinical relapse in the routine follow-up of patients with diffuse large Bcell lymphoma. Leuk Lymphoma. 2015;56(5):1261-5.

39. Feng JF, Liu JS, Huang Y. Lymphopenia predicts poor prognosis in patients with esophageal squamous cell carcinoma. Medicine. 2014;93(27):e257.

40. Regent A, Kluger N, Berezne A, Lassoued K, Moutho L. Lymphocytopenia: aetiology and diagnosis, when to think about idiopathic CD4(+) lymphocytopenia? Rev Med Interne. 2012;33(11):628-34.

41. Carr AC, Vissers MC, Cook J. Relief from cancer chemotherapy side effects with pharmacologic vitamin C. N Z Med J. 2014;127(1388):66-70.

42. Tanimura Y, Shimizu K, Tanabe K, Otsuki T, Yamauchi R, Matsubara Y, lemitsu M, Maeda S, Ajisaka R. Exercise-induced oxidative DNA damage and lymphocytopenia in sedentary young males. Med Sci Sports Exerc. 2008; 40(8):1455-62.

43. Kruger K, Mooren FC. Exercise-induced leukocyte apoptosis. Exerc Immunol Rev. 2014;20:117-34.

44. Pernice F, Floccari F, Nostro L, Caccamo C, Belghity N, Mantuano S, Romeo A, Barilla A, Aloisi C, Ruello A, et al. Oxidative stress, sister chromatid exchanges and apoptosis in the pathogenesis of lymphocytopenia in ESRD patients. J Nephrol. 2006;19(5):613-20.

45. Garcia-de-la-Asuncion J, Gomez-Cambronero LG, Del Olmo ML, Pallardo FV, Sastre J, Vina J. Vitamins C and E prevent AZT-induced leukopenia and loss of cellularity in bone marrow. Studies in mice. Free Radic Res. 2007:41(3):330-4.

46. Otsuka M, Matsuzawa M, Ha TY, Arakawa N. Contribution of a high dose of L-ascorbic acid to carnitine synthesis in guinea pigs fed high-fat diets. J Nutr Sci Vitaminol. 1999;45(2):163-71.

47. Famularo G, De Simone C, Trinchieri V, Mosca L. Carnitines and its congeners: a metabolic pathway to the regulation of immune response and inflammation. Ann N Y Acad Sci. 2004;1033:132-8.

48. Toliopoulos IK, Simos YV, Daskalou TA, Verginadis II, Evangelou AM, Karkabounas SC. Inhibition of platelet aggregation and immunomodulation of NK lymphocytes by administration of ascorbic acid. Indian J Exp Biol. 2011:49(12):904-8.

49. Hoffer LJ, Levine M, Assouline S, Melnychuk D, Padayatty SJ, Rosadiuk K, Rousseau C, Robitaille L, Miller Jr WH. Phase I clinical trial of i.v. ascorbic acid in advanced malignancy. Ann Oncol. 2008;19(11):1969-74.

50. Nielsen TK, Hojgaard M, Andersen JT, Poulsen HE, Lykkesfeldt J, Mikines KJ. Elimination of ascorbic acid after high-dose infusion in prostate cancer patients: a pharmacokinetic evaluation. Basic Clin Pharmacol Toxicol. 2015; 116(4):343-8.

\section{Submit your next manuscript to BioMed Central and we will help you at every step:}

- We accept pre-submission inquiries

- Our selector tool helps you to find the most relevant journal

- We provide round the clock customer support

- Convenient online submission

- Thorough peer review

- Inclusion in PubMed and all major indexing services

- Maximum visibility for your research

Submit your manuscript at www.biomedcentral.com/submit 